\title{
Work and the Shema
}

\author{
Stuart C. Weir
}

Stuart Weir is an independent scholar.

Since the Deuteronomic epoch Jews have been uttering the Shema Israel:

Hear, O Israel: The LORD is our God, the LORD alone. You shall love the LORD your God with all your heart, and with all your soul, and with all your might. (Deuteronomy 6:4-5).

It is a prayer which forms Jewish identity around the unmistakable claim that they belong to the monotheistic God of Israel. This God reveals himself to Israel as 'I AM WHO I AM' (Exodus 3:14), 'the God of Abraham, the God of Isaac, and the God of Jacob' (Exodus 3:6). The Shema therefore declares the Jewish theocratic worldview and the correlative ethical effort which must then stem from faith. All other prayers expressed are those which emerge from this centrifugal origin of communicating with God amongst one another.

The Christian Church, by virtue of its Jewish origins and acceptance of the Hebrew Bible, also pray this prayer with Jews. Jesus of Nazareth's use of the Shema ensured the Church's early and ongoing adoption of this especially Jewish prayer. In response to a question by a scribe of his day, as the intrigue around his teaching grew, Jesus cited the Shema. On this occasion there was no pejorative rejoinder to Jesus because his response was replete with sound theological orthodoxy (Mark 12:28-34). The Marcan account of this includes 'with all the strength' combined with heart and understanding. ${ }^{1}$ By so doing this triggers a demand upon human agency in response to the one and only God. Any inner yearning for God, in other words, will express itself in tandem with a physical manifestation of love. That this is the greatest commandment of all demands that we revisit its importance when confronted with fresh theological dilemmas. 
When considering the social conditions of current-day Scotland with (i) its breakdown in moral discourse; (ii) the bleak life-or-death T-junction offered in view of the ecological crisis; (iii) and the relentless idolatry of wealth which underlies (i) and (ii), the 'paradigmatic significance' of Deuteronomy's social programme for the theology of work could not be more significant today. ${ }^{2}$

\section{Hebraic holism}

Whether it is the Deuteronomic or its Septuagint equivalent that Jesus is recorded as using, it is notable that the heart/soul/might or heart/soul/ mind/strength clusters articulate something deeply significant about the make-up of those created to mirror God. There is a package of components which make up the human whole that work together as complementary strata to imago Dei. Such a collection harmoniously responds to the divine being in truth. There is no hint of the Hebrew worldview falling foul of Greek dualism which prioritises the soul/spirit over the body.

'Heart and soul' intimate the inner life of humankind; the life of the deep-seated self with its emotions and convictions, e.g. how you feel when you stand by the roaring of a winter North Sea, or the way you perceive a comment made with a certain tonality and force at a dinner party. As the old Talmudic maxim goes, 'We do not see things as they are. We see things as we are.' 3 'Mind' conveys the noetic and critical ability to reason, explain and understand the world surrounding it. The power of the human mind to debate complex matters with others and within oneself demonstrates profound cerebral agency. It reveals that innate human processing can build on the thinking of our forebearers and contemporaries as we are stimulated to push the limits of ideas and innovations. ${ }^{4}$ The functionality of neural pathways and how the plasticity of our brains can be moulded by knowledge are important expressions of the human mind.

But when we consider 'might/strength', this relates to bodily functions and practices. Strength relates to physical capacity and ability, whether much or little. Bodily presence also relates to our genetic make-up because of various potentialities that play their part in how human beings manifest their might in the world as persons (e.g., biological sex, the width of a person's shoulders, their height, their age at any current moment, the density of their bones, any history of injury or illness). Human physical features can vary from person to person and so how we are naturally

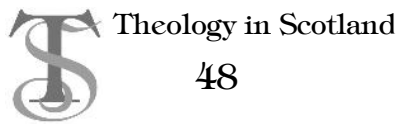


endowed in partnership with our fitness determine, if or to what extent, our strength can be deployed as a result of believing in the one true God. An intertwining of the 'heart/soul/mind/strength' cluster as integral strands of the human person manifest an acknowledgment of inexplicable feelings and experiences that people are and have as physical beings. Humans are 'enfleshed souls' or 'ensouled bodies' and so is their concomitant ability through emotional, physical and noetic means in complex blend. ${ }^{5}$

That the greatest commandment includes 'with all your strength' as part of the unique human gestalt ${ }^{6}$ confronts worshippers of the one true God seriously with everyday work as our ethical response to the monotheistic confession.

\section{A critique of the sedentary}

The problem with linking strength to our working lives today is that British (and therefore by extension, Scotland) working culture is predominantly sedentary. ${ }^{7}$ The mass shift from feudal society to industrialisation and then on again to information societies has ensured our worklives have increasingly become immobile and almost non-physical every day. Gone are the days of the pre-industrialised cottage industry where the family was the economic unit in the village composed of numerous other households who all produced something that was needful for trade with one another. ${ }^{8}$ Nor is there any living memory of how the ancients lived lives as huntergatherers and foragers, which demanded significant stamina to run down animal prey, nowadays called 'persistence hunting'. ${ }^{9}$ The industrialised world of work was often made up of places that put human bodies into action. The obvious contrast with feudal cottage industries were the materials with and conditions in which people were working, e.g. enormous metal machines which incessantly moved their perilous parts, creating immense noise, combined with very long working hours for factory wo/men. ${ }^{10}$

When information rather than making the physical objects which we need to flourish becomes the national focus, we end up with organisations large and small which hone the skill of information creation, shaping and sharing. This change in the forms of human work is due in large part to the rapid development of computer technologies. Our obsession with developing computer and phone technologies is one key factor to ensuring 
the longevity of a sedentary workforce. By creating such widespread, sedentary working opportunities, people are compelled to find alternative ways to stay physically fit after a long day at the desk. That some workers feel their best option is to leave their PC to enter unnaturally lit gyms to work their bodies on intricate technological equipment, breathing in stale, shared air, to synthesize their fitness is a non-sensical response. ${ }^{11}$ Because the vast majority of the workforce is sedentary, eventually there is an instinct to get the body moving so that obesity and forthcoming heart attacks can be avoided. That said, there will always be a percentage of society that works in a sedentary manner. For example, those who are of reduced physical capacity may be able to make a very meaningful contribution to society by working from a chair. The chair is the very location of the scholar's craft, unless s/he is standing at a rostrum. Even so, lecturing is typically done in a stationary fashion.

Working continually in a sedentary manner is directly linked to the obesity levels in Scotland. The Scottish Government's report, A More Active Scotland, admits that a sedentary Scotland is the major hindrance to physically fit human beings, and therefore 'encouraging and enabling the inactive to be more active is more important than ever. ${ }^{12}$ At no point in the document is the nature of work considered as a factor that needs rectified. Every possible corner is investigated but the form of work itself. There is a comprehensive workaround achieved in these recent government reports that fails to do deal with the locus of the problem. It is telling that the admission of the overarching obstacle to obesity in Scotland is the sedentary lifestyles. That the immobility and non-somatic nature of workers in Scotland is the issue is something that urgently needs to be addressed. Strikingly, the Scottish Health Survey 2018 identifies sedentary trends which only account for hours outside of work/school. ${ }^{13}$ Moreover, $30 \%$ of respondents cited 'lack of time' as the main barrier to being active and/or fit. But without any determination to create or encourage industries and sectors that require somatic fitness as intrinsic to work itself, obesity will not be addressed in as direct and thoroughgoing a manner as is required.

Furthermore, Scots in general have an added impediment, in that they often cannot accept they are "worthwhile person[s] who [have] the ability to act in the world in a way that is commensurate with his or her intentions. ${ }^{14}$ Both self-acceptance (feeling worthwhile) and self-efficacy (feeling confident about being effective) play a dual role in the measure of 
Scottish self-confidence to be active agents in the world. And given that, according to Scottish psychologist Alex Yellowlees, Scots lack such selfconfidence, this too is acutely concerning for somatic work. ${ }^{15}$ Without a mass of self-confident pioneers in Scotland to address non-somatic work in order to replace sedentary forms of work with salaried equivalents, Scotland is stuck with the status quo.

Over a century ago, the passing of the 1908 Small Holdings and Allotments Act enabled those who desperately needed sustenance an opportunity to grow food. There was no welfare state at this stage in British history. Reshaped into the contemporary information society, with its sedentary lifestyles and working patterns, salaried workers who receive an allotment still have the problem of lack of time and energy because such somatic work is additional to paid employment. There are only so many hours in a day.

Given the forms of work that information societies provide the opportunity for, promoting the ingredient of 'strength' from the Shema goes definitively against the tide. Indeed, the current trajectory of forms of work, as the sedentary nature of them disclose, have a 'mind only' focus. This is revealed by the growth of artificial intelligence. The trend has seen low paid Amazon shelf-pickers gradually being supplanted from their jobs by robots, a job that required them to walk around mass warehouses, keeping physically fit. ${ }^{16}$ On the other end of the salary scale there are skilled Caterpillar excavator operators who are being ousted from jobs because upgraded machines are being operated remotely via cables, lasers and gyroscope sensors. ${ }^{17}$ Moreover, there are even those who are interacting with technology so as to upload their minds permanently to the internet. ${ }^{18}$ By so doing, such persons seek to preserve themselves forever online, not solely for any progeny they may have but for anyone.

Such cerebral and non-somatic emphasis has been magnified during the COVID-19 pandemic. Technological adaptation has ensured very few face-to-face meetings and almost no travel (even on foot), including a vast reduction of commuting and the increase of sedentary work in front of a computer screen. The consequences of COVID-19 are pushing Scottish society to work as little as ever with physical strength. Given so glaring a lack of the somatic in Scottish working trends, it demands a response in view of the 'greatest commandment'. 


\section{The Shema and work}

To truly love the one true God with our whole person it is essential that we rediscover the mantra of the ancient Jewish community for our everyday work. The fact that Moses heard the voice of I AM WHO I AM from the inferno in the desert bracken whilst he was shepherding the flock should rightly be noted. This is an existential divine revelation in the midst of Moses' work. But it was only when Moses acted on I AM's demand that he took responsibility for God's people in a political manner, a craft far from his previous husbandry, that he began to love his neighbour as himself. By leading an ethnic migration out of a land by foot and beast after tense negotiations, Moses put an already weary Israel into motion. After imposed, slavish labour, God's people desperately needed the equilibrium that sabbath could offer. This latent rhythm set in motion by I AM Himself would only be initiated once they pushed through the pain of leaving their old slave masters and arriving at Mount Sinai. The incessant tyranny of work with no rest almost destroyed Israel.

At last the divine manifesto on stone slabs laid out work towards flourishing. In the first commandment, Israel were clearly instructed to not turn their work into an object of devotion. In the second commandment, by accepting the covenant relationship being imposed on them by I AM they were to develop no production of idols with materials to hand. In the fourth commandment, by finding rest for their weary bodies from work, as they came to terms with sabbath, Israel would find shalom without it being divorced from the necessity and meaningfulness of work. Furthermore, by following this pattern they were imitating the One who had brought all things into existence ex nihilo. Commandments three and five were generic enough to be within the orbit of transgressing whilst working, and the tenth commandment directly anticipated the green eyes of envy that would spread among the camp. This last of commandments seemed to identify the root cause that could precipitate breaking the sixth, seventh and eighth. The Decalogue, then, was a proto-Shema of sorts as it shaped Israel around loving God and one another in an inseparable manner.

The reign of Jehoshaphat, the eleventh hour of King Manasseh's reign, and King Josiah's reign were galvanised responses to the shape of their and all forthcoming Judahs. ${ }^{19}$ Working out together what Judah should be working on and the inherent purpose of all such projects was essential to the Deuteronomists given that Judah had such a long track record of 
idolatrous greed. Extricating themselves from their thanatological idolatry towards social acts of 'life' was their new remit so as to live lives of divine blessing. So too does Scottish society need, more than ever, a redeeming contour and trajectory in view of the bankruptcy of the idol that demands the knee: unbridled capitalism. Only by coming to our senses and seeking to conceive of work entirely differently can we claim to learn from the social Deuteronomists and the Shema. The fallout of so many through mental ill-health and post-COVID (or long COVID) fatigue as the ubiquitous virus continues to cause great strain to social life, and as the decimated job market mushrooms, must pressurise us to consider how and why we are working today. What are we working towards? ${ }^{20}$ What should we be working towards if the golden calf of global capitalism has not brought us to the Promised Land? ${ }^{21}$ Why does Scotland move at such a frenetic pace ${ }^{22}$ Are we moving in ways of Shalom? Are we heading in the direction of our heavenly home (John 14:2; Hebrews 11:10)? ${ }^{23}$ Without such teleological and eschatological connectivity work is rudderless and almost meaningless. That is why there is already such an existential crisis during the pandemic; global capitalism renders the little man even smaller than 'he' already is. ${ }^{24}$

In coming anywhere near answering such questions, one instrumental aspect that should be integrated into the theology of work is the bodily nature of work. The goal of physical human fitness in light of an increasingly obese Scotland through or at work must prominently feature in any renewed vision of work towards being the optimal bodily version of ourselves. This will no doubt bring us Scots into a better relationship with ourselves as it will with one another. Granted there will be numerous exceptions to bodily fitness as injury, illness and infirmity prevent it. But to ignore human physical ability is to work in contradiction to who we have been created to become. One significant strand of humankind as imago Dei, a strand that is oft forgotten, is the shalom of our relationship with ourselves. ${ }^{25}$ In societal terms this is known as 'mental (ill-)health', but also our physical fitness as it leads to greater resilience or as an end in itself. That the global obesity problem contributes significantly to mental ill-health is well documented. ${ }^{26}$

How do Scottish workers, then, love their neighbour when they loathe themselves? By occasionally and continually turning in on ourselves (incurvatus in se) through sedentary work, Scots denigrate this strata of mirroring God. And yet, in typical Lutheran form, as Emil Brunner 
counterbalances, "man is the being who stands "before God" even if he is godless. ${ }^{27}$ This lesser-known strand of human existence must coalesce with the three other strata of imago Dei: (i) our love of God; (ii) our relationships with others; and (iii) our interactions with non-human creation in order for us to flourish at work. Because 'only when we know how we image God will we be able to see how that imaging expresses itself coherently in the way that we order the world and our relationships. ${ }^{28} \mathrm{We}$ find here the symptoms of endemic issues as well as the problems themselves.

Only by recombining noetic, sympathetic aesthetics, and (limited) muscular effort in well-defined working projects can we begin to discover new connections in finding ourselves as we labour. If we are able to initiate meaningful forms of work that allow our bodies to flange with our ideas we will begin to become a richer version of ourselves, as previously siloed strands of personhood interweave with one another rather than running to the exclusion of our bodies. Our bodies should not be used in isolation from our minds as our minds have been used in isolation from our bodies.

Our physical ability must have an ethical rudder though. We cannot purely work on the basis of getting our bodies moving without a grander guiding telos. The way smartphones are made, for example, demonstrates just such teleological recklessness. To have a smartphone or tablet in every second pair of human hands at the expense of (i) child labour in the mining process for materials ${ }^{29}$ and (ii) exhausting the finite minerals required to produce them is so blatant an example of the dastardliness of utilitarian ethics. In this working process there is a clamouring after neodymium, terbium, dysprosium, and copper: seventy out of eighty-three nonradioactive elements from the periodic table used to produce our smart devices. This demonstrates an ethics driven by the financial bottom line at the expense of creation at large. Not only are these minerals already known to be finite, they are not being discovered at the rate required for demand for the global information 'system' because they are spread out in the earth in minute quantities. ${ }^{30} \mathrm{We}$ have existed for millennia before the advent of smart phones. We do not need to exercise children's bodies for this selfish mining endeavour only to rid the planet of its only fragments of said minerals. This is not the trajectory that work in partnership with the Shema should pursue.

Without a return to making things ourselves rather than subcontracting making to those who have little choice but to work for less money (e.g. in

a Theology in Scotland 
Far East Asian or Central European factories), we divorce ourselves from work that will enable us to pray and live according to the Shema. Unless we return to the production of things that will enable society to flourish, we deceive ourselves and continue to dance to the pied piper of global capitalism. ${ }^{31}$ As well as creating job opportunities and new pathways for skilled apprenticeships, relearning how to make things ourselves with materials that are not finite, nor harmful to us or non-human creation, we can learn the lessons of the social Deuteronomists. Only by taking the trouble to investigate what forms of work will lead us to life and not death can there be a path forward.

To push in a healthier direction, retrieving the spirit of the Arts and Crafts movement can re-educate humans towards careful making as the theology of work is informed by the Shema. Not only do new forms of work need to aid our flourishing, they must be instrumental towards putting bread on our tables. Any attempt to retrieve the English Romantics' vision for theo-aesthetics cannot be adrift from the necessity of sustenance. The instrumentality of work must coalesce with an ontology of work in order that humans become sanctified versions of themselves. When people at work combine being responsible for essential provisions with a teleological development of themselves in skill and physical fitness, a theology of work is shown to be influenced by the Shema. Working 'with all your strength' towards God naturally grafts into the doctrine of sanctification as workers intend to become physically and/or mentally stronger. The Hebraic holism previously noted necessarily includes our bodies as the Spirit of Christ makes us holy. As we work God works on us as the Great Sanctifier, and we are changed as a result. Working humans, then, exemplify not only plasticity of mind but of body too - not that workers ought to strive for eternal youth through fitness at work, but that workers maintain or improve their fitness in age-appropriate fashion.

The growth of veganism as a global reaction to the mass-mechanised farming of animals is one critical counter to the prevailing mass production of food with ever-dropping standards for the sedentary worker. Ever since industrialisation, work has been shaped so that the workforce works long hours to earn enough money to buy its food. ${ }^{32}$ The great irony of veganism is that although it rightly boycotts mass-mechanised farming, it still belongs to the same information-creating system that demands extra bodily exercise in addition to one's daily work like everybody else. Veganism has correctly identified the link between food intake and the

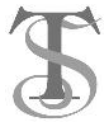

Theology in Scotland 
correlative fitness of bodies. Yet on the other hand, there are some who have latched onto veganism's eating regime as a dieting shortcut, not as a means of protest to the food production system that inveighs against animals and thus the quality of produce that goes into human bodies. Furthermore, to eschew the consumption of battery chickens whilst simultaneously stocking up on internationally imported avocados in exchange for cross-continent airplane emissions is an absurdity that requires serious acknowledgement. Protest of one system without a grander peripheral vision to equally grave problems demonstrates veganism's narrow response to food consumption. Veganism is thus only a partial response to the food industry. As a movement it lacks a broader response which could incorporate a challenge to workplaces as a whole, rather than large-scale farming alone.

The rhythm of repetition with hands that is required to chop meat accurately, with differentiation to provide ample types of meat cuts, at a certain degree of pace to serve customers promptly, and to treat dead beasts with fellow-creaturely respect, provide a point of focus to 'all your strength' ${ }^{33}$ For English Romantic John Ruskin, the value of meat that is respectfully treated from death to butchering to sale is derived from a vitalism that 'leads to life with its whole strength. ${ }^{34}$ Valere (to be well or strong) in the acquisition of cutting proficiency can move beyond rote mechanics for the butcher. 'Rhythm' in particular can aid the butcher to be active in ways that views each animal butchered as a fixed mode of time to spiritually work their body in accordance with the Deuteronomic maxim. ${ }^{35}$ The meticulous preparation of each carcass offers a holy opportunity to anticipate something important not only for the paying customer, but for the butcher's physical alignment to herself, as well as in relation to the beast. In aligning herself to worship the one true God, she finds that she loves her neighbours as she provides her community with prepared meat. ${ }^{36}$ It would not be remiss, for example, to adopt the Shema in a Benedictine fashion which weaves the desiring prayer into under-thebreath mutterings as work is accomplished. The infinite pendulum of labora with ora shares the impulse of the Shema in an equilibrium of the vita activa with the vita contemplativa. Such deliberate whispers to oneself keeps the telos of our work immediate in the same way any Jewish phylacteries strapped to head and hand do. ${ }^{37}$

By comprehending a value to work beyond the market price of silverside beef towards bodily flourishing, there is a service to life that is 
enacted. ${ }^{38}$ Ruskin states, for example: 'For as consumption is the end and aim of production, so life is the end and aim of consumption. ${ }^{39}$ As the butcher provides the cut of meat to the customer to consume, she accordingly has the energy to live life as she eats and is merry. Moreover, as the butcher swings her cleaver to provide the best cut possible, her honed motor skills afford a moment to worship the one true God 'with all [her] strength'. Whereas Ruskin rigidly eschews market value in puritanical fashion, workers need not be without the means of sustenance in discovery of a new somatic vista. When the two are combined, imago $D e i$ is enhanced as the Shema is enacted and recited. For a healthy theology of work must not view a means to putting bread on the table as unspiritual.

Moreover, if Chinese wet markets are indeed the originating source of COVID-19, then the skill (or lack thereof) of meat management is a timely form of work to rectify. Our interwoven relationships with non-human beasts must be in keeping with working on ourselves. Vegans, as I have shown, have long since identified this link. But in terms of a Christian theology of work, being human is to be imago Dei, which necessarily includes mirroring God through having dominion over all animal life. As such, to reshape society that drastically reduces urban woodland and park space is to curse that which we are asked to steward. Bird, small mammal and insect life is curtailed when we eclipse these needful spaces for the next block of flats. By so doing, we not only squeeze them out of existence, but it truncates the possibility of human flourishing in the process. This is seen clearly, for example, in the sharp reduction of bees required for pollination in order to grow food for humans, even though bees produce honey itself. ${ }^{40}$ Ironically, industrial-scale agriculture is to blame for much of this issue. Jettisoning some of our machines to work somatically in harmony with animal life in lieu of eradicating that which is also created, particularly if/when we decide to butcher an animal, is required to manage this world appropriately and with due care.

This bodily connection to Deuteronomy's 'public theology'41 highlights the lack of current workplaces that afford such somatic focus. As societies across the globe review why we work at all, and what work should be invested in in the first place, attention should be directed to forms of work that encourage our bodies to be part of the work itself. If such a theological idea can be activated in creative ways that also 'brings in the bacon', a somatic revival in work could take hold. By taking stock 
of the global COVID-19 situation, even though the circumstances of the pandemic are begetting working trends in the opposite direction, reassessing how work in partnership with the Shema can amount to flourishing is the narrow path Scotland should seek.

By crafting a spirituality of work that takes a fuller account of the Deuteronomic prayer 'Hear, O Israel', which moves its utterers to working in a way that ignites soul, mind and body, we can learn to implement afresh the greatest commandment as integrated in active Christian living. By being so attentive to the Shema and its demands for an ethical response to the God of Abraham, Isaac, Jacob and Jesus in our everyday work, Christians might look up to discover that they too 'are not far from the kingdom of God' (Mark 12:34). ${ }^{42}$

\section{Notes}

1 On Jesus' use of the Shema, see Scot McKnight, The Jesus Creed: Loving God, Loving Others (Brewster, Mass.: Paraclete Press, 2004).

2 Timothy Gorringe, Capital and the Kingdom: Theological Ethics and Economic Order (Maryknoll, N.Y.: Orbis, 1994), Introduction.

3 Babylonian Talmud: Tractate Berakoth. https://halakhah.com/berakoth/ berakoth_55.html.

4 Stuart C. Weir, The Good Work of 'Non-Christians', Empowerment, and the New Creation: The Efficacy of the Holy Spirit (Eugene, Or.: Pickwick, 2016), 208-10.

5 For expanded explanations of 'enfleshed souls' and/or 'ensouled bodies', see Jürgen Moltmann, God in Creation: An Ecological Doctrine of Creation, trans. Margaret Kohl (London: SCM Press, 1985), X.\$2.2.

6 'Configuration'.

7 Owen Gough, "Sedentary society: UK workers spend nine hours a day sitting down", 24 February 2017. https://smallbusiness.co.uk/ sedentary-workers-day-sitting-2537056/.

8 Andrew Walker, Enemy Territory: The Christian Struggle for the Modern World (London: Hodder \& Stoughton, 1987), 122.

9 George C. Frison, Survival by Hunting: Prehistoric Human Predators and Animal Prey (Berkeley: University of California Press, 2004). 
10 Richard Sennett, The Craftsman (London: Penguin, 2008), 81-118.

11 Michael S. Northcott, A Moral Climate: The Ethics of Global Warming (London: Darton, Longman and Todd, 2007), 207.

12 Scottish Government, A More Active Scotland: Scotland's Physical Activity Delivery Action Plan, 2018, https://www.gov.scot/binaries/ content/documents/govscot/publications/strategy-plan/2018/07/active -scotland-delivery-plan/documents/00537494-pdf/00537494-pdf/govscot $\% 3 \mathrm{~A}$ document/00537494.pdf, 13. Government analysis of this issue takes a multifaceted approach to contributing factors: Scottish Government, The Scottish Health Survey 2018, https://www.gov.scot/ publications/scottish-health-survey-2018-volume-1-main-report/pages/51/, chapter 6 .

13 Scottish Health Survey 2018, chapter 6.

14 Carol Craig, The Scots' Crisis of Confidence (Edinburgh: Big Thinking, 2003), 7.

15 Cited in Craig, Crisis, 6.

16 Jason Del Rey, "How robots are transforming Amazon warehouse jobs for better and worse", Vox, 11 December 2019, https://www.vox.com/ recode/2019/12/11/20982652/robots-amazon-warehouse-jobs-automation.

17 David Berreby, "The Robots are Here", National Geographic, September 2020, 46.

18 Jerry Adler, "The Quest to Upload Your Mind into the Digital Space", Smithsonian Magazine, May 2015, https://www.smithsonianmag.com/ innovation/quest-upload-mind-into-digital-space-180954946/.

19 Gorringe, Capital, vii.

20 I have no need to develop what are already excellent treatises on the necessity of a theological teleology of work: Darrell Cosden, A Theology of Work: Work and the New Creation (Carlisle: Paternoster, 2004); John Hughes, The End of Work: Theological Critiques of Capitalism (Oxford: Blackwell, 2007), 97-136.

21 Craig Bartholomew and Thorsten Moritz, eds., Christ and Consumerism: A Critical Analysis of Spirit of the Age (Carlisle: Paternoster, 2001); Robert Wuthnow, ed., Rethinking Materialism: Perspectives on the Spiritual Dimension of Economic Behavior (Grand Rapids, Mich.: Eerdmans, 1995).

22 Walter Brueggemann, Sabbath as Resistance: Saying No to the Culture of Now (Louisville, Ky.: Westminster John Knox Press, 2014). 
23 David W. Smith, Seeking a City with Foundations: Theology for an Urban World (Nottingham: IVP, 2011).

24 Rajini Vaidyanathan, "Indian factory workers supplying major brands allege routine exploitation”, BBC News, 17 November 2020, https://www.bbc.co.uk/news/world-asia-54960346.

25 Thanks to Darrell Cosden of Pacific Theological College, Fiji, who seeded this thought in his lectures at International Christian College, Glasgow in 2001.

26 Tim Bradshaw and Hilary Mairs, "Obesity and Serious Mental Ill Health: A Critical Review of the Literature", Healthcare 2, no. 2, (2014): 168-69.

27 Emil Brunner, Dogmatics Volume II: The Christian Doctrine of Creation and Redemption, trans. Olive Wyon (London: Lutterworth, 1952), 60.

28 Tom Smail, Like Father, Like Son: The Trinity Imaged in Our Humanity (Milton Keynes: Authentic Media, 2005), 56.

29 Annie Kelly, "Apple and Google named in US lawsuit over Congolese child cobalt mining deaths", The Guardian, 16 December 2019, https://www.theguardian.com/global-development/2019/dec/16/apple -and-google-named-in-us-lawsuit-over-congolese-child-cobalt-miningdeaths.

30 David Nield, "Our smartphone addiction is costing the Earth", Tech Radar, 4 August 2015, https://www.techradar.com/uk/news/phone-andcommunications/mobile-phones/our-smartphone-addiction-is-costingthe-earth-1299378.

31 William McDonough and Michael Braungart, Cradle to Cradle: Remaking the Way we Make Things (New York: North Point Press, 2002); Mary Portas, Work Like a Woman: A Manifesto for Change (London: Black Swan, 2019).

32 Acquiring food has been achieved in industrial and information societies through self-sufficiency initiatives such as allotments (albeit they have their origins from Anglo-Saxon times). The National Allotment Society, "Brief History of Allotments", https://www. nsalg.org.uk/allotment-info/brief-history-of-allotments/.

33 Sennett, Craftsman, 175-77.

34 This is somewhat ironic given that the beasts end up dead! John Ruskin, Unto This Last (No location: Filiquarian Publishing, 2007), 72. 
35 This argument is controversially used in favour of whaling. For the arguments surrounding this topic, see: Alexander Gillespie, "The Ethical Question in the Whaling Debate", Georgetown International Environmental Law Review 9, no. 2 (1997): 355-387.

36 Gene Edward Veith, Working for Our Neighbor: A Lutheran Primer on Vocation, Economics, and Ordinary Life (Grand Rapids, Mich.: Christian's Library Press, 2016).

37 See also Karl Barth's theology of work which espouses work as prayer: Evangelical Theology: An Introduction, trans. Grover Foley (London: Collins, 1965), 148-58. (Original work published 1962.)

38 Hughes, End of Work, 228.

39 Ruskin, Unto This Last, 85.

40 Sandra Dick, "Dramatic decline in pollinators threatens food chain", The Herald, 27 March 2019, https://www.heraldscotland.com/news/ 17529012.dramatic-decline-pollinators-threatens-food-chain/.

41 Walter Brueggemann, Deuteronomy (Nashville, Tenn.: Abingdon Press, 2001), 19.

42 I am grateful to the Masters student who mooted the correlation between work and the Shema as I taught two seminars on the theology of work at Cliff College, England in September 2016. To my regret I have forgotten his name! 